\title{
PSYCHOLOGICAL EMPOWERMENT OF POLITICALLY EMPOWERED WOMEN LEADERS IN RURAL AREAS
}

\author{
Dr. Namita Kumari Das \\ Asst. Prof in Psychology, Dhenkanal Autonomous College, Dhenkanal, Odisha \\ DOI: 10.46609/IJSSER.2021.v06i06.024 URL: https://doi.org/10.46609/IJSSER.2021.v06i06.024
}

\begin{abstract}
The process of women's empowerment has five dimensions, such as cognitive, psychological, economic, political, and physical dimensions. The psychological dimension encompasses the belief that women can act at personal and community levels to improve their condition and the society in which they live. The political facet requires that women can analyse, organise, and mobilise for social change. The Government of India has taken many initiatives to empower women and provide them equal status with men. For the political empowerment of women, one of the major interventions taken by the government is to empower women through the Panchayat Raj Institutions (PRIs). The plan programmes and schemes implemented by the Panchayati Raj Department are poverty alleviation and employment generation programme, basic services programme, infrastructure developmental programme, capacity building programme, and various welfare schemes. The success of these welfare schemes depends widely on the skill and efficiency of sarapanchas who are the representative or leaders of rural people. The study intends to know the need and analyse the importance of psychological empowerment of rural women political representatives. The study attempts to develop a conceptual model or framework for the psychological empowerment of rural women political representatives (sarpanch).
\end{abstract}

Keywords: psychological empowerment, community, Panchayati-raj, welfare schemes, sarpanch

\section{Rationale}

Empowerment of women implies developing the women as more aware individuals, who are politically active, economically productive, and independent and can make intelligent discussion in matters that affect them(Koko,1992). Women empowerment has been an important research topic in the field of gender studies, social and organizational psychology for more than two decades. Women empowerment as a concept was introduced at the International Women Conference in 1985 at Nairobi. Developing a belief in one's ability to make desired changes, and the right to control one's life is considered a factor of women's empowerment. 


\section{International Journal of Social Science and Economic Research}

ISSN: $2455-8834$

Volume:06, Issue:06 "June 2021"

The process of women's empowerment has cognitive, psychological, economic, political, legal, and physical dimensions (Malhotra, et al, 2002). The cognitive dimension refers to women having an understanding of the conditions and causes of their subordination. The psychological dimension includes the belief that women can act at personal and societal levels to improve their realities and the society in which they live. The economic factor requires that women have access to, and control over productive resources. The political aspect requires that women can analyse, organise, and mobilise for social change. And the physical facets of empowerment involve gaining control over one's body and sexuality and the ability to protect oneself against sexual violence (Unifem).

Empowerment as a motivational construct (psychological empowerment) reflects an individual's active orientation to his work role, with his cognitions being shaped by a work environment (Spreitzer, 1995). Psychological empowerment exists when employees feel that they exercise some control over their work-life (Spreitzer, 1995). According to Spreitzer and Quinn (1997) empowerment is a mindset or an active orientation that an employee has about his role in the organisation. Spreitzer (1995) proposed that individuals with a high level of psychological empowerment perceive their work as meaningful and believe they have the competence and an impact on their work, which leads to proactive behaviors in their work situation. Aryee and Chen (2006) found that empowerment is positively associated with organizational commitment, job satisfaction, and task performance.

According to Zimmerman (1995), psychological empowerment is a construct composed of three interrelated components: 1) an intrapersonal component, which includes cognitive appraisals of control, competence, determination, and motivation; 2) an interactional component, composed of critical skills and knowledge; and 3) a behavioral component, including participatory, changeoriented behaviors in formal and informal contexts and organizations. It has been suggested that these three components are positively correlated with one another.

The Government of India has taken many initiatives to empower women and provide them equal status with men. Many welfare schemes have been implemented from time to time by both the central and state governments for girls and women. Reservations in the field of education, employment, income generation, and the political sphere have been provided to women to ensure empowerment. To build up the process of empowerment of women and to ensure their development, many schemes such as ICDS, Mission Sakti, Ujjawala, Janani Surakshya Yojana, Swadhar, Working Women Hostel, Swayam Siddha, STEP, etc. have been initiated and implemented by the government. For the political empowerment of women, one of the major interventions taken by the government is to empower women through the Panchayat Raj Institutions (PRIs), so that to ensure their participation in the process of political decision making. 
International Journal of Social Science and Economic Research

ISSN: 2455-8834

Volume:06, Issue:06 "June 2021"

\section{Political Vs Psychological Empowerment}

Panchayati raj system is so designed as to bring democracy and empowerment to the rural people. Panchayati-raj aims to induce people's participation in decision-making and the implementation of developmental programmes and schemes for their upliftment. The 73rd amendment of the Constitution of India enforced in the year 1993 marks the beginning of a new trend in the history of India. The Act provided for a new Panchayati raj system with its special features like the establishment of gram sabha in each village and three-tier system of PRIs at the village, block, and district levels, reservation of seats for STs, SCs, and women; a uniform fiveyear term for PRIs; decentralization of power; authority and responsibilities to panchayats; financial autonomy to the panchayats; and a separate state election commission to conduct elections to PRIs on the completion of the term. With the gram panchayat at the village level, the sarpanch is the key figure and functionary who plays the central role in the panchayat.

As the whole of India, in Odisha, the village panchayats have been the oldest unit of local selfgovernment. The Panchayati- Raj System in Odisha contains all these features. In 2011, the reservation for women in PRIs has been increased to 50\% in Odisha. Some other states also sanctioned 50\% of seats for women at the panchayat level. The Gram Panchayat Act deals with the power, duties, and functions of Gram Panchayat. All the executive powers of the Gram Panchayat are vested in the sarpanch. The sarpanch convenes and presides over the meetings of the Gram Panchayat and is responsible for the proper maintenance of the records and proceedings of the meetings. He/she supervises the acts, rules, and proceedings of the Gram Panchayat and controls all officers and employees of the Panchayat. Sarpanch has to exercise such other power, discharge such other duties and perform such other functions as may be assigned to by the Government from time to time. As $50 \%$ of the total seats are reserved for women, $50 \%$ of the sarpanches are women in many states.

Although the constitutional amendments and reform measures taken by the government from time to time emphasizes the transfer of power from the top level to the lower level, it is still not known whether the women sarpanches feel genuinely empowered. In other words, if the constitutional reforms and subsequent legislations intended to empower women are to succeed, it is critical to understand the extent to which all women sarpanches perceive their work and the environment as empowering. This aspect involves a motivational construct of empowerment.

The plan programmes and Schemes implemented by the Panchayati Raj Department are poverty alleviation and employment generation programme, basic services programme, infrastructure developmental programme, capacity building programme, e-governance, etc. These programme have evolved for the empowerment of vulnerable \& marginalized sections of the society who are still under deprivation. The success of these welfare schemes depends widely on the skill and 


\section{International Journal of Social Science and Economic Research}

ISSN: $2455-8834$

Volume:06, Issue:06 "June 2021"

efficiency of sarpanches who are the representative or leaders of rural people. If the representatives are suffering from any kind of shortcomings or hindrances on the personal level, how can they work for empowerment and upliftment of the people who elect them?

Indian women representatives at the rural level often perceive themselves as having little control over their work, and most sarpanches call their husbands or other male members as their authority who takes all decisions. Although the constitutional amendments and reform measures taken by the government from time to time emphasizes the transfer of power from the top level to the lower level, it is still not known whether the women sarpanches feel genuinely empowered. In other words, if the constitutional reforms and subsequent legislations intended to empower women are to succeed, it is critical to understand the extent to which all women perceive their work and the environment as empowering. It is on this backdrop, the investigator decided to develop a model of psychological empowerment in Panchayati-raj institutions which may be considered by researchers, policymakers, NGOs, and other concerned authorities

\section{Empowerment of Rural Women Leaders: Some Observations}

The psychological empowerment of women plays a significant role in their overall growth and development. In India, very few studies have been undertaken to study the impact of psychological empowerment. So far our knowledge is concerned about the psychological empowerment of women in different occupations in general and in rural local self-government, in particular, has not been studied.

Panda (1996) in her study of village panchayats in Orissa found that women representatives have entered into politics only due to the mandatory provision of reservation or pressure from their family members. A study by Narayan (2005) observed that women became members because the seat was reserved for them and not because of their role in public life, and most of them were unknown faces. Nilekani (2010) studied the reservation pattern in the Karnataka GP system and found women presidents of GP as powerless while, male members of their families or vice presidents of GP held the actual power. A study by Singh (2009) on panchayat members, officials, and villagers in Agra district of Uttar Pradesh revealed that women in Uttar Pradesh have always remained on the periphery, which is due to illiteracy, proxy candidature, low status of women in the family, and society, early marriage, poverty, the burden of domestic chores, etc.

Several other studies reveal that reservation itself cannot bring empowerment of women unless there is a positive change in the social structure and attitude of the people. Sekhon's (2006) study has explored women's participation in panchayats. She contends that reservations alone are not a sufficient condition for empowerment because women are constrained by a variety of sociocultural, economic, and political factors. The traditional gendered beliefs of the role and status of 


\section{International Journal of Social Science and Economic Research}

ISSN: $2455-8834$

Volume:06, Issue:06 "June 2021"

women in family and community, caste and class inequalities, lack of education and awareness, and lack of legal knowledge are some major hindrances which are needed to be addressed for the empowerment of women. As the Indian social structure is patriarchal where women are not fully educated and dependent on their family members, they cannot take part in the decision-making process with full freedom. Moreover, although they get a political position through gender quota but are supposed to work as proxies for their husbands or other family members.

Kaul and Sahni (2009), in their study analyses the level of elected women representative"s participation in panchayat and the difficulties faced by them. They have judged the participation of elected women members based on meetings attended by women members in panchayats, decisions taken by these women members, and freedom of speech in panchayats. Their findings illustrate that neither the reservation for women nor their actual presence in the panchayat has helped in addressing the problems associated with the common village women. According to them, elected women representatives were not always given due respect, their suggestions were not seriously considered and sometimes their opinion bears little significance in the decisionmaking process. Since they were women, their views and opinion was not given due weightage and they were bound to endorse the decisions taken by their husbands or other male family members or by the male-dominated village panchayats.

Based on the above literature the main conclusions are

1. Political empowerment through reservations itself cannot bring psychological empowerment because women are constrained by a variety of social-cultural, economic, and political factors.

2. The provision of gender quotas in Panchayati-raj institutions has helped improve the status of women by involving them in the decision-making process although they come across many difficulties in the course of their participation.

3. Psychological empowerment is a mean as well as an end in itself without which the attainment of women empowerment in general and women empowerment, in particular, is incomplete. In this context, the development of a model or framework is necessary to achieve psychological empowerment in every field and profession.

\section{A model of Psychological Empowerment}

We have sufficient reasons to develop a model of psychological empowerment for the women sarpanch. First, to our knowledge, no such model has been developed to explore the psychological empowerment phenomenon among Indian rural local representatives in general and female representatives in particular. This has limited our understanding of this matter. Second, when compared with other professions that women engaged in in India, political 
representation at the local level is a profession that is in more need of empowerment. Because, the sarpanches are leaders who are entrusted with the responsibility of implementing and monitoring many welfare schemes, social security schemes, poverty alleviation programmes, awareness programmes, empowerment programmes, etc. launched by the central as well as state governments. The successful implementation of the plan and programmes depend to a larger extent on the efficiency of the sarpanches. The duties and responsibilities of a sarpanch involve extensive knowledge, initiative, effective communication, leadership quality, and above all dedication. In this context, the psychological empowerment of women is highly required.

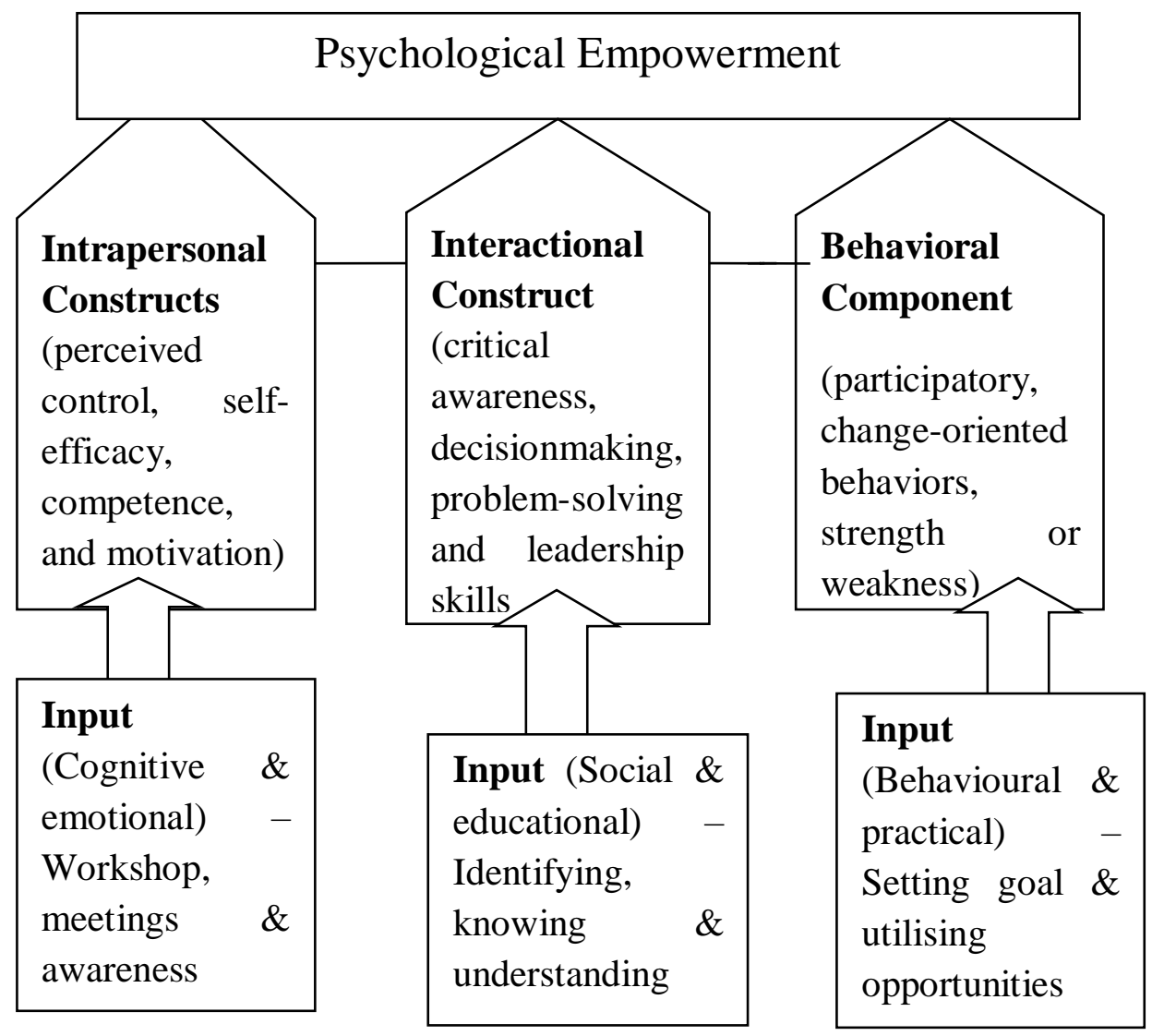

\section{Figure1. A Conceptual model of Psychological Empowerment for rural women political representatives (sarpanch)}

The conceptual model shown in Figure 1 provides researchers with a theoretical position to conduct studies on the psychological empowerment of women leaders in Panchayati-raj institutions. This model is constructed to answer the following research question: How can the 


\section{International Journal of Social Science and Economic Research}

ISSN: $2455-8834$

Volume:06, Issue:06 "June 2021"

intrapersonal, interactional, and behavioural factors play role in empowering psychologically the women leaders at the panchayat level? Zimmerman (1995, 2000) describes intrapersonal empowerment as people's own beliefs about their ability to control their environment and achieve their goals. It is perceived as the emotional component of psychological empowerment and focuses on a person's feelings about her inner world (Kasturirangan, 2008). Based on Zimmerman (2000), the intrapersonal empowerment construct is indicated by one's perceived control, self-efficacy, competence, and motivation. For the elected women leaders in rural areas perceived control concerns with their actions and reactions towards improving their socioeconomic condition in family and community.

Bandura (1977) hypothesized that the prospect of personal efficacy establishes whether coping behaviour will be initiated, how much effort will be expended, and how long it will last in the face of difficulties. Bandura proposed a model in which the potential of personal efficacy is derived from information about previous performance accomplishments, experience, verbal persuasion, and physiological states. According to him, it is the experience of mastery arising from the effective performance of work assigned that has the most positive effect on people's sense of empowerment. Self-efficacy focuses on their ability and performance in the decisionmaking process after acquiring the necessary knowledge and skill and obtaining self-direction in achieving the desired goal. Human beings accomplish this by learning through trial and error activities. The individual is continually motivated toward a more competent interchange with the environment. Competence here relates to their understanding and capabilities on the practical aspects of Panchayati-raj as well as the exercise of authority. Motivation is related to the inner forces that drive them to use their knowledge and authority to improve their socio-economic well-being and solve community issues.

According to Zimmerman (2000), it is people's analysis and understanding of their external conditions, the social and political environment comprises the construct of the interactional construct. The interactional construct is reflected in critical awareness, decision-making, problem-solving, and leadership skills. For women sarpanch in rural areas, critical awareness refers to their awareness level regarding the policy and programmes of the Panchayati-raj system initiated and implemented by the government from time to time. Zimmerman (1995) state that interactional empowerment could involve new insights, information, and knowledge, and could include being able to identify useful resources, knowing how to access these resources, and understanding barriers to resource access. Concerning the women sarpanch, the interactional construct consists of their decision-making, problem-solving, and leadership skills in village panchayats. Behavioral component of psychological empowerment comprises an individual's strengths or competencies and would vary with the goals and opportunities available. For the women leaders at the rural level, this construct reflects in their efforts to engage in panchayat 


\section{International Journal of Social Science and Economic Research}

ISSN: $2455-8834$

Volume:06, Issue:06 "June 2021"

activities, keeping in touch with the new plan and programmes initiated by the government from time to time and improving their socio-economic conditions.

\section{Conclusion}

Many studies have been carried out to study different aspects of women's empowerment. Very few studies have focused on the importance of psychological empowerment. The introduction of reservation for women in Panchayati-raj institutions is a giant step taken by the government to ensure the equal status of women in participatory democracy. Though the socio-economic condition of women has been changed due to reservation of seats, adequate input concerning intrapersonal, interactional, and behavioural components will strengthen the psychological aspect of empowerment and ultimately will lead to work motivation, enthusiasm, satisfaction, and success. The proposed conceptual model is an attempt to create a greater understanding and application of psychological empowerment in the Panchayati-raj system. The model may be the basis of research to examine the importance of the constructs of psychological empowerment. It can be used with different populations in different locations engaged in different occupations.

\section{References}

Aryee, S. \& Chen Z.X. (2006). Leader-member exchange in a Chinese context: Antecedents, the mediating role of psychological empowerment and outcomes. Journal of Business Research, 59(7): p. 793-801.

Bandura, A (1977) 'Self-efficacy: Toward a Unifying Theory of Behavioral Change', Psychological Review, vol. 84, no. 2, pp. 191-215.

Deci, E., J. Connell, and R. Ryan, (1989) Self-determination in a work organization. Journal of Applied Psychology. 74: p. 580-590.

Kasturirangan, A. (2008). The Balance of Psychological Empowerment and Disempowerment for Survivors of Domestic Violence. Unpublished Ph.D., University of Illinois, Chicago.

Kaul Shashi and Sahni, Shradha (2009) Study on the participation of women in Panchayati raj institution, Stud Home Comm Sci, 3(1): 29-38

Koko, U. (1992). "Empowering People for Health and Family Planning", IASSI Quarterly, Vol.11, p. 2,

Malhotra Anju, Schuler, S. R., and Boender. C., (2002), “Measuring Women's Empowerment as a Variable in International Development", Background Paper Prepared for the World Bank Workshop on Poverty and Gender: New Perspectives 
International Journal of Social Science and Economic Research

ISSN: 2455-8834

Volume:06, Issue:06 "June 2021"

Maliheh, Z, Fateme Z., and Hasan Ashrafi-rizi. (2015) "Relationship Between Psychological Empowerment and Productivity of Medical Librarians," Journal of Academy of Medical Sciences of Bosnia and Herzegovina, Online Journal 23(3), pp.142-146.

Narayana, D. (2005), "Local Governance without Capacity Building: Ten Years of Panchayati Raj Economic and Political Weekly, Vol. 40, No. 26, Jun 25 -Jul 1, pp.2822-2832.

Narayanan, Usha (1999), "Women's Political Empowerment: Imperatives and Challenges", Mainstream, April 10, p-7.

Nelson, D. \& Quick, J. (2012) Principles of Organizational Behavior: Realities and Challenges.'Australia: South-Western.

Nilekani Janhavi (2010), 'Reservation for Women in Karnataka Gram Panchayats The Implications of Non-Random Reservation and the Effect of Women Leaders', Economics Senior Essay, Yale College, New Haven, USA.

Panda, S. (1996), "Empowering Pattern of Leadership among Rural Women in Orissa", Indian Journal of Public Administration, Volume 42., No. 3-4.

Quinn, R.E., \& Spreitzer, G.M., (1997). The road to empowerment: seven questions every leader should consider. Organizational Dynamics, 26(2), 37-48,

Sekhon J. 2006, 'Engendering grassroots democracy: research, training, and networking for women in local self-governance in India', NWSA Journal, Vol. 18 No. 2 (summer)

Singh, Y. (2009). Social Praxis, Conceptual Categories, and Social Change: Observations from a Village Study. Sociological Bulletin, 58(2), 178-195. Retrieved July 25, 2021, from http://www.jstor.org/stable/23620684

Spreitzer, G.M., (1995). Psychological empowerment in the workplace: Dimensions, measurement, and validation. Academy of Management Journal,.38: p. 1142-1465

Spreitzer, G.M., M.A. Kizilos, and S.W. Nason, (1997). A dimensional analysis of the relationship between psychological empowerment and effectiveness, satisfaction, and strain. Journal of Management, 23: p. 679-704.

Website of Ministry of Women \& Child Development, Govt. of India

Website of Women \& Child Development, Panchayati-raj, Govt. of Odisha.

www.unifem.org. 
International Journal of Social Science and Economic Research

ISSN: 2455-8834

Volume:06, Issue:06 "June 2021"

Zimmerman, M.A., (1995). Psychological empowerment: Issues and illustrations. American Journal of Community Psychology, 23: p. 581-599.

Zimmerman, M. A. (2000). Empowerment Theory: Psychological, Organizational and Community Levels of Analysis. In J. Rappaport \& E. Seidman (Eds.), Handbook of Community Psychology (pp. 43-63). New York: Kluwer Academic/Plenum Publishers. 